DEPARTMENT OF THE INTERIOR

U.S. GEOLOGICAL SURVEY

\title{
THE RELATION OF WATER QUALITY TO GEOLOGY AND LAND USE CHANGES IN FAIRFAX COUNTY AND VICINITY, VIRGINIA
}

\author{
By A. J. Froelich and Chester Zenone
}

